The authors present a very rare case of a giant pleomorphic adenoma arising from the parapharyngeal space with penetration to the pterygopalatine fossa and skull base in a 62-year old patient. The authors put emphasis on diagnostic and surgical treatment of tumours in this anatomical region. It is necessary for surgical treatment of tumours in this area to be carried out by a multi-specialty laryngological-neurosurgical team, having long-term experience in skull base surgery.

Key words: parapharyngeal space, pterygopalatine fossa, skull base, pleomorphic adenoma.

\section{Extensive pleomorphic adenoma of parapharyngeal space with pterygopalatine fossa and skull base penetration - case report}

Rozległy guz mieszany przestrzeni przygardłowej penetrujący w obszar dołu skrzydłowo-podniebiennego i podstawy czaszki - opis przypadku

Tatiana Gierek ${ }^{1}$, Jarosław Paluch ${ }^{1}$, Jarosław Markowski', Czesław Zralek², Maciej Kajor ${ }^{3}$, Edyta Jura-Szołtys ${ }^{1}$, Małgorzata Witkowska ${ }^{1}$

1ENT Department, Silesian Medical University, Katowice, Poland ${ }^{2}$ Neurosurgery Department, Silesian Medical University, Katowice, Poland 3 Pathomorphology Department, Silesian Medical University, Katowice, Poland

\section{Introduction}

The parapharyngeal space, having the shape of a reversed pyramid, is located in a lateral position in relation to the upper and middle pharynx. The base of the parapharyngeal space reaches the base of the skull, while its apex reaches downward from the hyoid bone [1].

Tumours of this region occur rarely and constitute $0.5 \%$ of all neoplastic tumours of the head and neck region. About $80 \%$ of them are non-malignant tumours, while the remaining $20 \%$ are malignant ones [2].

The largest group of parapharyngeal space tumours is that of mixed tumours, occurring in some $40-50 \%$ of cases [3].

Ranking second in frequency of occurrence is the group of neurogenic non-malignant tumours: ganglioneuroma, neurofibroma, paraganglioma, neurilemoma; as well as malignant ones: neurofibrosarcoma, schwannosarcoma, sympathicoblastoma [4].

\section{Case report}

A female patient, J.O., age 62, was admitted to our clinic due to very slowly increasing, over a period of one year, dysphagia and lockjaw as well as accompanying pain in the left side of the face. Laryngological examination revealed a smooth-wall tumour filling the nasopharynx along the median line, as well as the middle and lower pharynx on the left side.

A fine-needle biopsy (FNB) was performed, using the approach through the oral cavity (examination No. BC/827/06), obtaining the pleomorphic adenoma result.

Basic laboratory investigations did not reveal changes. The MR imaging of the facial skeleton revealed an extensive expansive alteration of the parapharyngeal space on the left side, having the dimensions of up to $8 \mathrm{~cm}$ in the cranio-caudal dimension and $5 \mathrm{~cm}$ in the longitudinal and sagittal dimension. The tumour was located in the parapharyngeal space, reaching in its upper part to the level of the lower wall of the left maxillary sinus and the infratemporal region, downward to the level of the left submandibular gland over the length of some $8 \mathrm{~cm}$. In the medial part a substantial mass effect was observed - the lesion bulges towards the nasopharynx and the oral part of the pharyngeal cavity, causing compression and displacement of those 
W pracy przedstawiono rzadki przypadek guza mieszanego ogromnych rozmiarów wywodzącego się z przestrzeni przygardłowej i penetrującego w obszar dołu skrzydłowo-podniebiennego i podstawy czaszki u 62-letniego pacjenta. Autorzy omówili diagnostykę przedoperacyjną oraz opisali technikę operacyjną usunięcia guza. Podkreślili konieczność wykonania operacji przez doświadczony zespół laryngologiczno-neurochirurgiczny ze względu na lokalizację guza.

Słowa kluczowe: przestrzeń przygar dłowa, dół skrzydłowo-podniebienny, podstawa czaszki, guz mieszany. structures to the right, to the level of the upper parts of the lower pharynx at that level the epiglottis and symmetric epiglottic valleculae do not reveal compression or displacement. In the posterior upper and medial part it is directly adjacent to the adjoining bone structures - sphenoid bone and partly to vertebral column structures, without indication of their displacement. In the lower part the lesion is adjacent to the vascular fascicle, causing its dislocation to the back, and connects to the left parotid gland. The described lesion reveals heterogeneity in signal intensity; it also undergoes non-homogeneous intensification upon the administration of contrast medium. The borders of the lesion are fairly well delineated, polycyclic in character. The brain structures in the examined region do not reveal pathological signals (Fig. 1)

Conclusion: extensive expansive alteration of the parapharyngeal space on the left side.

\section{Description of surgical procedure}

The patient was qualified for a laryngological-neurosurgical procedure.

The incision of the skin was arch-like, at the level of the zygomatic bone, prolonged in parallel fashion to the zygomatic process of the temporal bone. The soft tissues, including the temporal muscle, were separated. The zygomatic process of the temporal bone was exposed, then it was temporarily detached and taken to the side, together with the skin and muscle flap. That provided access to the pterygopalatine fossa from the upper-posterior side. The presence of an encapsulated tumour was revealed, the tumour penetrating to the base of the skull. It was removed partly using the abovedescribed approach. The remaining tumour mass was removed via the transoral approach. The surgical procedure itself and the postoperative period were without complications.

The result of histopathological examination of the postoperative mixed tumour preparation confirmed the result of the aspiration fine-needle biopsy (Fig. 2). The patient has been followed up for a year, without signs of recurrence.

\section{Discussion}

The authors present a case of extensive polymorphic adenoma of the parapharyngeal space with penetration to the skull base, confirming the reports of other researchers about the asymptomatic development of tumours in that region in the early stages of the disease [2-4].

Consistent information in the literature confirms that only tumours having a diameter of 2-3 cm may cause lesions found on clinical examinations [2].

The symptoms reported by patients in the first stage of disease are nonspecific, manifested as a feeling of having an obstacle in the throat, which was also confirmed by the examination of the subject in the case described here $[2,4]$.

In accordance with the accepted diagnostic standards, in order to state the presence of tumour in the parapharyngeal space it is necessary to perform palpation examination using both hands, whereas the initial histopathological diagnosis is made on the basis of the FNB examination $[1,4]$.

The extent of the tumour, its location and relation to adjoining anatomical structures should be determined on the basis of CT (computed tomography) or MRI (magnetic resonance imaging).

In the course of diagnosis of the presented case, the above recommendations were complied with. On the basis of that diagnosis the female patient was qualified for a surgical procedure, which is the therapeutic method of choice for parapharyngeal space tumours $[1,2,4]$.

Because the tumour penetrated to the pterygopalatine fossa and skull base the surgical procedure was performed by an interdisciplinary team of laryngologists and neurosurgeons. 

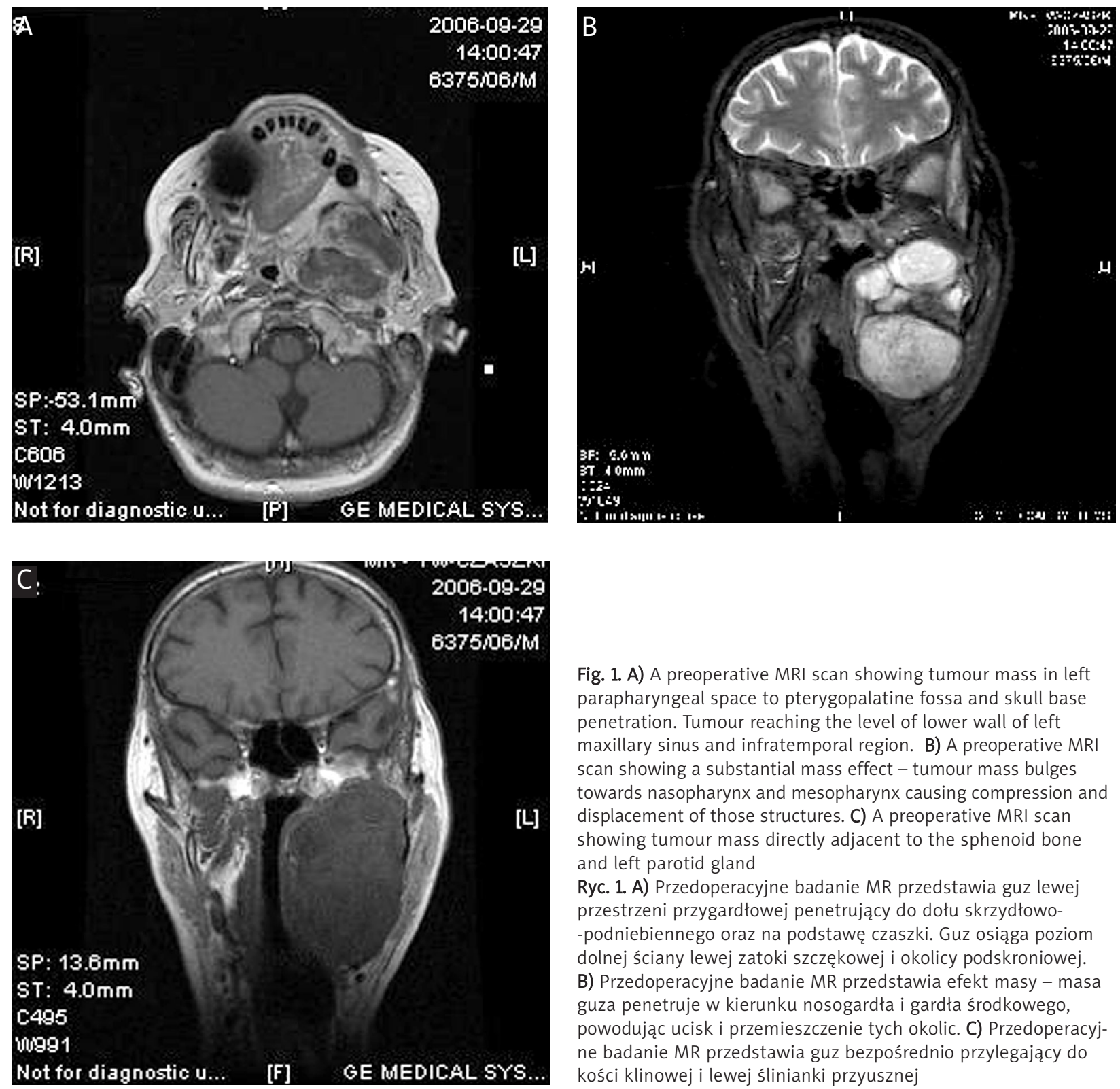

Fig. 1. A) A preoperative MRI scan showing tumour mass in left parapharyngeal space to pterygopalatine fossa and skull base penetration. Tumour reaching the level of lower wall of left maxillary sinus and infratemporal region. B) A preoperative MRI scan showing a substantial mass effect - tumour mass bulges towards nasopharynx and mesopharynx causing compression and displacement of those structures. C) A preoperative MRI scan showing tumour mass directly adjacent to the sphenoid bone and left parotid gland

Ryc. 1. A) Przedoperacyjne badanie MR przedstawia guz lewej przestrzeni przygardłowej penetrujący do dołu skrzydłowo-podniebiennego oraz na podstawę czaszki. Guz osiąga poziom dolnej ściany lewej zatoki szczękowej i okolicy podskroniowej.

B) Przedoperacyjne badanie MR przedstawia efekt masy - masa guza penetruje w kierunku nosogardła i gardła środkowego, powodując ucisk i przemieszczenie tych okolic. C) Przedoperacyjne badanie MR przedstawia guz bezpośrednio przylegający do kości klinowej i lewej ślinianki przyusznej
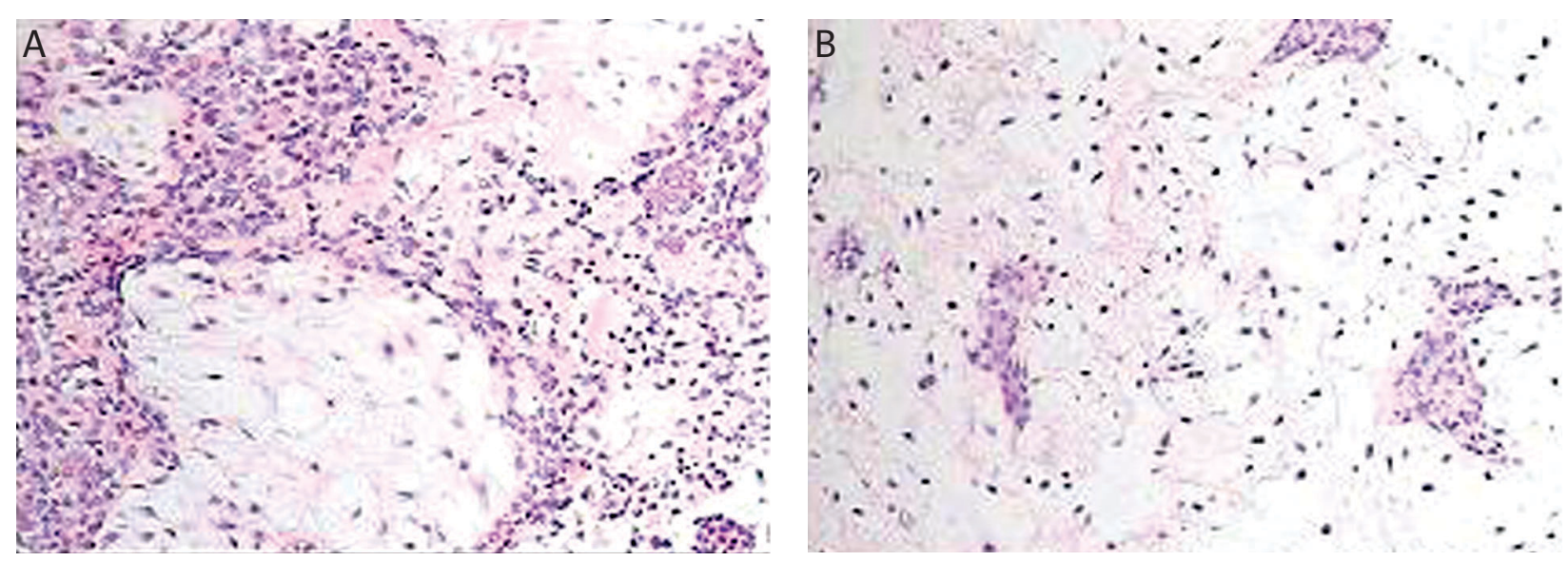

Fig. 2. Photomicrographs showing histology of tumour tissue; pleomorphic adenoma. Haematoxylin \& Eosin stain, original magnification $\times 100$

Ryc. 2. Fotografia przedstawia obraz histopatologiczny tkanki guza: gruczolak wielopostaciowy. Barwienie hematoksylina i eozyna, powiększenie $100 x$ 
To obtain access to the parapharyngeal space, various surgical approaches are used, which result from the tumour topography and size, as well as the personal experience of the surgeon.

The most preferred approaches are: through the neck, through salivary glands, cervical-parotid, cervical-pharyngeal (with or without median mandibulotomy), through the oral cavity or the infratemporal fossa $[5,6]$.

On the basis of the diagnostics carried out in the analysed case the decision was taken to carry out the procedure using the subtemporal approach connected with the approach through the oral cavity, which allowed for radical removal of the tumour.

In conclusions:

1. The process of diagnosing tumours of the parapharyngeal space, due to the fact that symptoms appear late and are not characteristic, requires additional imaging diagnostics and FNB.

2. Due to complicated anatomical conditions the treatment of parapharyngeal space tumours should be performed in centres with substantial experience in surgery of head and neck carcinomas.

3. Tumours of the parapharyngeal space which penetrate to the base of the skull require interdisciplinary treatment by a laryngological-neurosurgical team.

\section{References}

1. Gehrking E, Gellissen J, Wollenberg B. Chirurgie der parapharyngealen adenome. HNO 2007; 55: 135-44.

2. Pang KP, Goh CH, Tan HM. Parapharyngeal space tumors: an 18 year review. J Laryngol Otol 2002; 116: 170-5.

3. Ahmad F, Waqar-Uddin, Khan MY, Khawar A, Bangush W, Aslam J. Management of parapharyngeal space tumours. J Coll Physycians Surg Pak 2006; 16: 7-10.

4. Luna-Ortiz K, Navarrete-Aleman JE, Granados-Garcia M, HerreraGomez A. Primary parapharyngeal space tumors in a Mexican cancer center. Otolaryngol Head Neck Surg 2005; 132: 587-91.

5. Shahinian H, Dornier C, Fisch U. Parapharyngeal space tumors: the infratemporal fossa approach. Skull Base Surg 1995; 5: 73-81.

6. Har-El-G. Combined endoscopic transmaxillary-transnasal approach to the pterygoid region, lateral sphenoid sinus, and retrobulbar orbit. Ann Otol Rhinol Laryngol 2005; 114: 439-42.

7. Kanazawa T, Nishino H, Ichimura K. Pleomorphic adenoma of the pterygopalatine fossa: a case report. Eur Arch Otorhinolaryngol 2000; 257: 433-5.

\section{Address for correspondence:}

Jarosław Markowski PhD, MD

Katedra i Klinika Laryngologii

ul. Francuska 20

40-027 Katowice

e-mail: jmarkow1@poczta.onet.pl 